\title{
Тувинские традиционные методы точных расчетов при изготовлении каркаса юрт
}

\section{Валерий О. Ооржак}

Тувинский институт комплексного освоения природных ресурсов СО РАН,

Российская Федерация

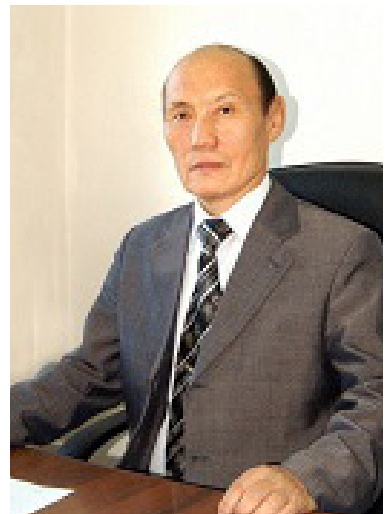

В статье представлены методы расчетов, которые использовались тувинскими мастерами при изготовлении каркаса тувинской юрты, в частности, верхнего круга хараача.

Эти методы обеспечивали надёжность, долговечность конструкций и их оригинальные возможности изменения размеров и конфигурации юрты в соответствии с сезонами года, приспособляемость традиционного жилища к различным природным, климатическим условиям и явлениям. Особенно важно было соблюдать заранее рассчитанные параметры при выполнении отверстий-пазов в хараача - верхнем круге, в которые вставляются верхние концы улун (ынаа) - жерди-стропила юрты.

Подробно описаны методы и способы расчетов, замеров и сам процесс подготовки, сверления и совершенствования конфигурации пазов хараача при их изготовлении. Разработаны и показаны чертежи-схемы (проекты) традиционных методов проведения расчетов, замеров, способов и приспособлений.

Ключевые слова: юрта; строительство юрты; изготовление юрты; жилище кочевника; тувинцы; традиционная технология; хараача; тувинская юрта; тувинская культура

Ооржак Валерий Окпан-оолович - кандидат экономических наук, старший научный сотрудник Тувинского института комплексного освоения природных ресурсов СО РАН. Адрес: 667007, Россия, г. Кызыл, ул. Интернациональная, д. 117а. Тел.: +7 (394-22) 662-77 доп. 13. Эл. адрес: v.oorgak@yandex.ru

OORZHAK, Valeriy Okpan-oolovich, Candidate of Economics, Senior Researcher, Tuvinian Institute for Exploration of Natural Resources, Siberian Branch, Russian Academy of Sciences. Postal address: 117a Internatsionalnaya St., 667007 Kyzyl, Russian Federation. Tel.: +7 (394-22) 662-77 extension number 13 E-mail: v.oorgak@yandex.ru 


\title{
Tuvan traditional methods of precise computation in the making of yurt frame
}

\author{
Valeriy O. Oorzhak \\ Tuvinian Institute for Exploration of Natural Resources, Siberian Branch of the Russian Academy of Sciences, \\ Russian Federation
}

The article examines methods of computation used by Tuvan craftsmen in making the Tuvan yurt frame, in particular its upper circle known as "kharaacha".

These methods provided reliability and durability of the structures and the yurt's unusual feature of changing size and configuration according to a specific season. Traditional Tuvan house is thus adaptable to various natural and climatic conditions and phenomena. It was especially important to maintain the precalculated parameters in making grooves in kharaacha (upper circle), into which the upper ends of ulun (ynaa, rafters of the yurt) were inserted.

The article gives details of computation methods, measurements, and the process of preparing, drilling, and improving the configuration of kharaacha grooves during their making. It also shows plans and drafts of traditional calculation methods, measurements, and devices.

Keywords: yurt; yurt building; yurt making; nomadic house; Tuvans; traditional technology; kharaacha; Tuvan yurt; Tuvan culture

\section{For citation:}

Oorzhak V. O. Tuvinskie traditsionnye metody tochnykh raschetov pri izgotovlenii karkasa iurt [Tuvan traditional methods of precise computation in the making of yurt frame]. New Research of Tuva, 2020, no. 4, pp. 64-79. (In Russ.). DOI: www.doi.org/10.25178/nit.2020.4.5

\section{Введение}

В современных условиях динамичных преобразований и модернизации, процесс взаимодействия традиционной культуры с индустриальной цивилизацией является одной из актуальных проблем социально-экономического развития регионов. Происходящие при этом прогрессивные процессы нельзя оценить однозначно. В то же время такое взаимодействие, как правило, ведет к кризису культур, называемых традиционными, а зачастую и к их исчезновению. В частности, если речь идет о малых народах, в особенности об их традиционных, выработанных многовековым опытом методах производства, приспособленных к местным природно-климатическим условиям и особенностям образа жизни и деятельности. В каждом регионе такие процессы отличаются определенной спецификой. В Туве к таковым, наряду с другими, можно отнести некоторые традиционные методы и способы проведения точных расчетов использовавщихся для изготовления каркаса юрты. А они были бы бесцены при условии их востановления и принятия за основу при разработке новых, современных технологий.

Тематике юрты, в том числе тувинской, уделено определённое внимание ученых, исследователей (см.: Майдар, Пюрвеев, 1980; Вайнштейн, 1991; Байыр-оол, 2013; Бохоева, Балданов, 2013; Ултургашева, Тиникова, 2013; Кан-оол, Ондар, 2014; Кокова, Толмашов, 2014; Никифоров, Михайлов, Никифоров, 
2014 и др.). В то же время, по нашему мнению, малоизученными остаются особенности традиционных технологий производства юрт, а именно - методов и способов изготовления оригинальных конструкций и элементов каркаса юрты в соответствии с требованиями и правилами, выработанными вековыми практиками и мастерством изготовителей.

Особую актуальность данное направление исследований приобретает и в связи с поиском путей решения проблем, возникающих при адаптации этнокультурных практик к задачам их усовершенствования и модернизации, в том числе и при реализации Индивидуальной программы социальноэкономического развития Республики Тыва, утверждённой распоряжением Правительства Российской Федерации от 10 апреля 2020 года № 972-р. ${ }^{1}$

Целью данной работы является выявление особенностей тувинской традиционной технологии изготовления каркаса юрты, методов и способов проведения точных расчетов, которые могут быть использованы для усовершенствования традиционного быта кочевников - модернизации производства юрт. Они необходимы также и для возрождения, сохранения и развития традиционных видов хозяйствования и туризма, в том числе при реализации социально значимых программ, ориентированных на развитие животноводческих ферм.

Данное исследование требует применения междисциплинарного подхода, причем учитывающего методы и результаты как социальных, так и естественных наук. Источниковой базой для нас выступили авторские полевые материалы, собранные во время учебы, работы, выездов в районы республики и в Монголию:

- в 1965-1972 гг. в Бай-Тайгинском районе, при (во время) участия в изготовлении юрт (в качестве ученика) у дедушки М. Д. Саая, у народных мастеров; Б. Ш. Саая, М.-Д. С. Хертек, К. М. Саая (в том числе при изготовлении юрты для национального музея республики), рассказы-воспоминания старых народных умельцев, собственные воспоминания от наблюдений и услышанных рассказов-наставлений старших мастеров по изготовлению юрт;

- в 1984-1991 гг. во время выездов в целях сбора материалов для проектирования и организации цеха по производству юрт в Чаданском Райпромкомбинате, совместно со специалистами райпромкомбината, проектного бюро Минместпрома Тув АССР, и встречи с народными мастерами в Дзун-Хемчикском, Сүт-Хөлском, Барун-Хемчикском, Бай-Тайгинском, Тес-Хемском, Эрзинском районах и в Монголии.

Также источниками нашего исследования стали материалы из фондов и архивов Национального музея Республики Тыва, рассказы-вспоминания научных сотрудников музея; авторские наблюдения за производством и эксплуатацией юрт в настоящее время, за методами и способами работы современных мастеров по изготовлению каркасов юрт, за проблемами, возникающих при изготовлении и использовании каркасов юрт, и сами юрты, произведённые различными способами, в различных условиях (в цехах и кустарных), в том числе выставляемые администрациями кожуунов и городов на торжествах и праздниках, например, на таких, как День живодноводов Наадым.

Автор опирался так же и на работы ученых Тувинского института гуманитарных прикладных социально-экономических исследований при Правительстве Республики Тыва, Тувинского государственного университета, Тувинского института комплексного освоения природных ресурсов СО РАН по проблемам адаптации коренных жителей Тувы к рынку труда в современных условиях, определения потенциала этно-экономической культуры населения региона, разработки концепций и стратегий развития республики и др.

\section{Традиционные требования и правила изготовления юрты тувинцев}

Многовековая практика изготовления и использования кочевой юрты позволила выработать правила ее изготовления с точными пропорциями, условиями сбора и демонтажа, а также формами и способами украшения, мебелировки. Каждый элемент юрты и вся её конструкция изготавливались как наиболее оптимальные для того, чтобы соответствовать образу жизни кочевников, резко-континентальным, суровым природно-климатическими условиям мест их проживания, кочевок в различные времена года. Все правила вырабатывались во время практического использования юрт

\footnotetext{
${ }^{1}$ Правительством Российской Федерации утверждена Индивидуальная программа социально-экономического развития Республики Тыва, 16.04.2020 [Электронный ресурс] // Министерство экономики Республики Тыва. URL: http://mert.tuva.ru/directions/fcp/news/366.html (дата обращения: 05.05.2020).
} 
и опирались на расчеты и анализ качества и свойств материалов. В том числе и были разработаны оригинальные (специфические), ныне во многом утраченные методы и способы определения размеров, расчетов углов наклона конструкций, величины гнутья элементов стен, замеров, заготовки и сушки материалов и другие особенности технологии производства, использовавшиеся мастерами при изготовлении каркаса юрты.

В то же время необходимо отметить, что технологии производства юрт у разных культур, в разных регионах, где её использовали и используют, отличаются и по используемым материалам, и по методам, и способам изготовления. Так же и в разных районах Тувы технологии производства некоторых частей (конструкций) юрты у разных мастеров имели свои особенности, отличающиеся друг от друга, но с соблюдением общих правил, требований и принципов. В том числе это касалось используемых материалов, ряда методов и способов производства отдельных элементов. При заготовке материалов для каркаса юрты, некоторые мастера, в частности братья Сенди Сегбеевич Хертек (1913-1974) и Догбал Сегбеевич Хертек (1911-1971), иногда использовали тополь, осину и даже ель, хотя основными материалами всегда считались тальник и берёза. Раньше почерк известных народных умельцев был легко узнаваемым - по методам и способам работы, по качеству их изделий, по сырью и материалам, используемым при изготовлении и отделке (украшении) отдельных элементов каркаса юрты.

Некоторые из изделий, благодаря мастерству их создателей, считались шедеврами. К таковым можно отнести специально или по заказу изготовленные самыми опытными и знаменитыми мастерами оригинальные штучные изделия, такие как верхний круг - хараача - полусферическая конструкция; или входной дверь юрты и другие элементы каркаса и покрытия. Хараача изготавливались разных размеров, в разных конфигурациях, в том числе были двухъярусные, из разных материалов и разными способами: способом гнутья из ствола молодой берёзы, тополя или осины, способом соединения (склеивания) специально заготовленных и высушенных особыми способами кривых частей из корня берёзы, который считался самым крепким, долговечным и назывался дугай хараача. Такие хараача высокого качества, изготовленные из самых крепких материалов, и отделывали в соответствии с пожеланиями заказчика качественными влагоотталкивающими покрытиями с последующей покраской и красивой орнаментацией. Некоторые мастера оформляли хараача красивой резьбой по дереву, причём не только основной корпус хараача, но и мөгеже - выгнутые, прямоугольные в сечении, деревянные рейки, крестообразно располагаемые и крепко закрепляемые на основной корпус хараача по 3-5 штук. Всего устанавливают от 6-ти до 10-ти штук мөгеже, за счет которых и формируют полусферическую несущую верхную часть хараача.

Конечно такие специально штучно сделанные по заказу изделия стоили дорого. Со слов народного мастера, лауреата Государственной премии им. Репина К. М. Саая (1931 г. рожд.), хорошо сделанная знаменитыми прославленными шеверами (мастерами) один дугай хараача стоил от молдурга (телёнок годовалый, молодняк - бычок, телка или як на втором году), до коровы с телёнком или коня в зависимости от размеров, качества и отделки. При этом у обычных мастеров целый комплект каркаса небольшой юрты весь мог стоить корову с телёнком, а простые, гнутые со ствола молодой берёзы хараача оценивались в одного барана или овцу с ягнёнком. Примерно также отличались по цене и другие части конструкции каркаса юрты, в зависимости от размеров и качества изготовления. Мастер говорил мне, что были случаи когда за качественно изготовленную по заказу большую юрту с 8-ми или 10-ти звеньевыми хана (стенами), богатые люди отдавали целый табун лошадей Бир аскыр өөр чылгы, т. е. около 30-40 лошадей во главе с вожаком-жеребцом.

Были мастера, которые в ходе многолетнего оттачивания своего искусства вырабатывали новые, теперь бы сказали авторские, виды конструкций или их отдельных частей и узлов, новые способы и методы их проектирования и изготовления, в частности, при изготовлении хараача, его своеобразных отверстий - пазов. Одними из таких мастеров, с которыми мне посчастливилось встречаться в период 1969-1973 гг., наблюдать за тем как они работают, помогать в качестве ученика, был младший брат моего дедушки Быдаакай Шойдайович Саая (или как его звали в народе - Өг чазаар Быдаакай, мастер (столяр) по изготовлению каркасов юрт) (1905-1975) и самый младший брат бабушки, знаменитый камнерез Мижит-Доржу Сегбеевич Хертек (1913-1974).

Б. Д. Саая был из числа тех редких мастеров, которые сумели сохранить старинные секреты изготовления каркасов, так называемых эдэ тиктинер - изменяющих форму или үрелбес (быжыг) өг - не ломающихся, долговечных, или универсальных юрт. Его современники, в том числе и знаменитый камнерез, член Союза художников СССР, лауреат Государственной премии РФ им. И. Е. Репина М.-Д. С. Хертек, говорили что искусник умел особенно хорошо изготавливать верхние круги юрты 
хараача по традиционной технологии, по так называемой методике дугай хараача - цельного круга из корней берёзы. Он делал каркасы юрт разных размеров, от 5-ти до 8-ми метров в диаметре.

Улуг-даай (уважаемый дядя) Быдаакай Шойдайович был ещё очень общительным, доброжелательным человеком. Он с удовольствием рассказывал, какие были и есть народные правила и требования к качеству элементов каркаса юрты, и какие бывают способы и методы их изготовления. Отвечал даже на мои вопросы относительно способов изготовления любого элемента каркаса юрты. Многое из того, что я часто слышал из его рассказов, смыслы его наставлений, осталось в памяти. В частности, он давал наставления следующего содержания:

«Өгбелеривистиң үндезилеп тургузуп каан негелделерин, дүрұмнерин, өөредиглерин, чурумнарын, санаашкыннарын, катап тургузуп, сагыыр болза, чүгле ынчан ёзулуг эки шынарлыг Тыва өглерни кылып болур».

Дословный перевод:

«Настоящую тувинскую юрту хорошего качества можно будет изготавливать только тогда, когда будут полностью восстановлены традиционные требования к качеству, те правила, методы расчетов, и способы изготовления, которые были выработаны нашими предками за многовековую практику».

Вот некоторые из этих требований, правил и учений (опять же восстановленные по памяти из его рассказов):

«Өгнүң дээвиириниң чайгы эң улуг ийленчээн - кадырын (чваскыр чайын) дөрбелчинниң чартыы чедир улгаттырып болур кылдыр кылыр болза эки, а кыжын ооң үштүң биринге чавызадып турар кылдыр».

Перевод:

«Каркас юрты надо изготавливать таким образом, чтобы были возможности увеличить максимальный уклон покрытия-потолка (в дождливое лето) до половины прямого угла (квадрата), то есть до $45^{\circ}$ ), а зимой снизить на одну треть»).

Автор статьи попытался воссоздать схему-чертёж конфигураций сезонных вариантов установки одной и той же юрты, изготовленной в соответствии с этими традиционными народными требованиями (рис. 1-3).

«Улуннарның, дээвиирниң ийленчээн, хараачаның ұттериниң хевирин, хемчээлдерин, ийленчээн шын caнаn, шыйыn, белеткеп, тургаш тодарадып кылып хандырар» («Изменение углов наклона всех улун (стропил), соответственно потолка юрты в целом, должно быть обеспечено за счёт точных расчётов, замеров по определению размеров, конфигурации и наклона отверстий - пазов хараача и их правильного, в соответствии с расчетами, изготовления» (рис. 4).

На рисунках 1-3 показаны схемы-чертежи возможных вариантов установки (конфигурации) тувинской кочевой юрты в разные времена года. Представленные возможности изменения физических показателей (параметров) юрты (высоты, общей площади, объёма) обеспечивался народными мастерами при изготовлении каркаса юрты посредством соблюдения традиционных требований и применением так называемого правила эде тиктинер өг (универсальная, или изменяющая конфигурацию, юрта) и использования метода ийи катап улгаттырар (двукратного увеличения) при изготовлении отверстияпазов хараача - дугай хараяча (верхнего круга) и концов улун.

В рассматриваемом варианте взяты размеры бичи өг (маленькой юрты) или чиик өг (лёгкой юрты) одной наиболее мобильной видов юрт облегченной конструкции. Длина улун подобной юрты равна ly = $225 \mathrm{~cm}$, диаметр хараача $\varnothing \mathrm{x}=120 \mathrm{~cm}$.

Под обозначением «B-1» (на рис. 1) нарисован общий вид (схема) юрты в среднем варианте установки в весенний и осенний сезоны года, с частичным показом каркаса, покрытия, двери и ряда других элементов укрепления, утепления и вентилирования. При среднем варианте установки (угол наклона улун, значит и потолка-покрытия $-35^{\circ}$ ), диаметр юрты составляет 5,0 метра, общая высота $\mathrm{H}_{1}=3,15$ м, высота хана (стенки) $h_{1}=1,65$ м. Общая площадь юрты Sю будет равна $S ю \pi r^{2}=3,14 \times(2,50 \times 2,50)=$ $3,14 \times 6,25=19,625 \mathrm{M}^{2}$.

Под обозначением «B-2» (на рис. 2) составлена схема-конфигурация варианта установки той же юрты в зимний период. Здесь, как видно из схемы-рисунка, диаметр юрты увеличен до 5,30 м, при тех же конструктивных элементах, за счет снижения угла наклона улун (ынаa) - стропил на одну треть с первоначального, то есть до $25^{\circ}$, соответственно и снижения высоты хана до $\mathrm{h}_{2}=1,50$ м. Таким способом, 


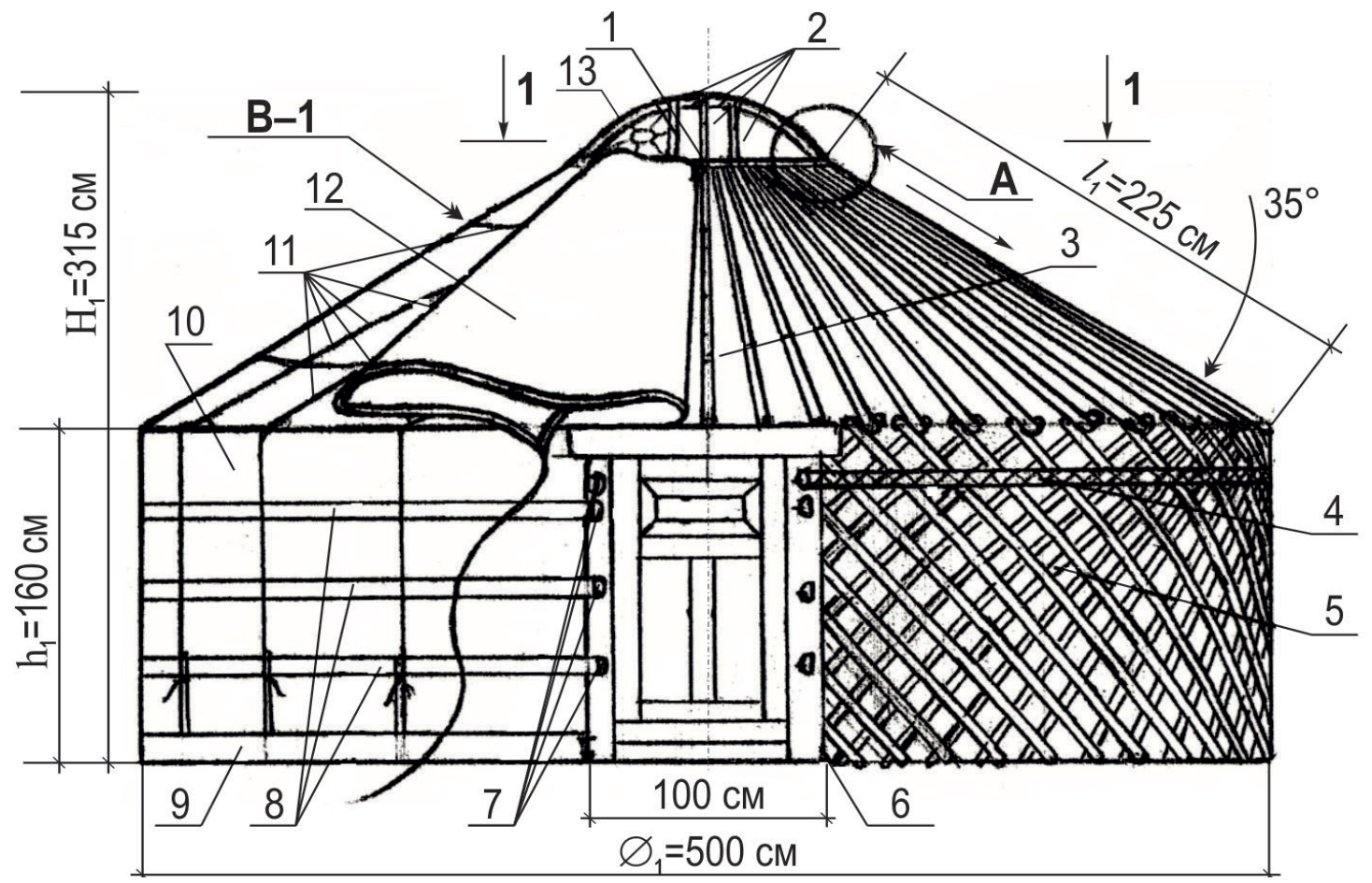

Рис. 1. Общая схема-чертёж основного варианта 1 (В-1 конфигурации) установки тувинской юрты весенний и осенний сезоны года.

Fig. 1 A general view and plan of variant 1 (configuration B-1) of setting up a Tuvan yurt in the spring and fall seasons.

Условные обозначения: 1 - хараача (верхний круг - полусферическая конструкция, состоящая из основного круглого корпуса и закреплённых на ней реек - мөгежелер); 2 - мөгеже (ровно выгнутые деревянные рейки, крестообразно располагаемые и крепко закрепляемые на основной корпус хараача по 3-5 штук в каждом направлении креста, всего устанавливают от 6-ти до 10-ти шт.); 3 - улун (деревянные балки, жерди; они служат несущими конструкциями для всего покрытия юрты); 4 - иштики (башкы)

кур, (внутренний (первый) “пояс", который располагают и стягивают первым по верхней части снаружи стен, но внутри покрытий юрты); 5 - хана (решётчатые стены каркаса юты, состояшая из 6-8-ми звеньев); 6- эжик (дверь); 7 - дээрбек (Әээрбектер) - (кольца с двух сторон двери, устанавливают по 4-5 шт., для привязывания внутреннего и наружных “поясов”); 8- даштыкы курлар (наружные "пояса", располагают снаружи покрытий стен, по 3-5 штук, на равномерные (одинаковые) расстояния между ними, на всю высоту хана); 9 - хаяапча (полоска из специального войлока шириной 20-30 см., укладывают снаружи покрытий, для утепления, вокрух нижней части стен юрты); 10 - адакы (покрытия нижней вертикальной части стен из слоёв войлока и ткани); 11 - базырыктар (верёвки для стягивания и укрепления покрытий юрты); 12 - дээвиир (покрытия верхней конусообразной части юрты из слоёв войлока и ткани); 13 - өреге (самая верхная прямоугольная (квадратная) часть покрытия юрты, которой закрывают полностью полусферическую верхную часть хараача, и открывают в дневное время до половину хараача); А-узел примыкания улун к хараача; $l$ - размер длины улун; $H$-высота юрты при разных вариантах установки; $h$-высота хана (стен) юрты при разных вариантах установки; $\varnothing-$ диаметр юрты.

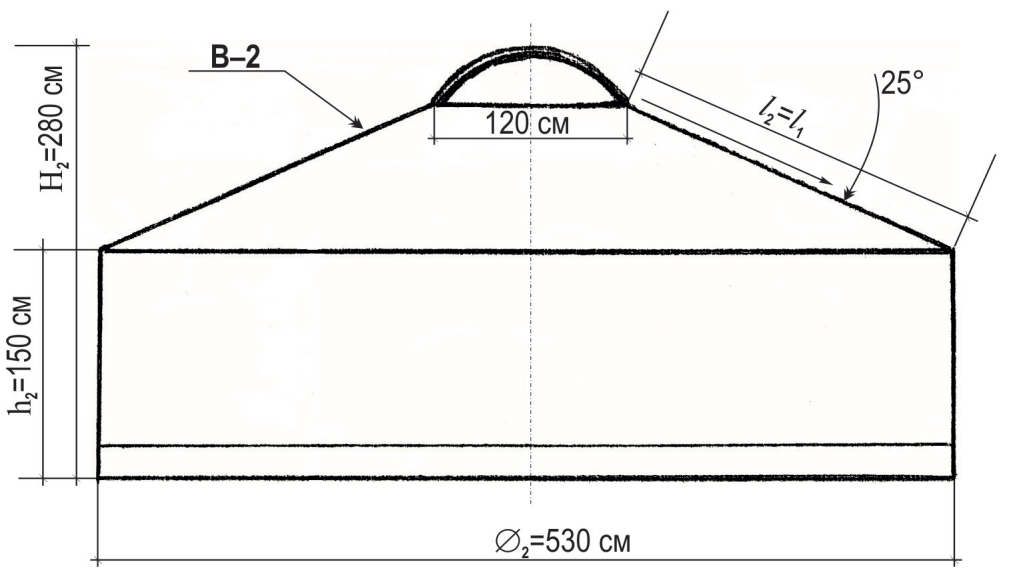

Рис. 2. Общая схема-чертёж установки варианта 2 (В-2 конфигурации) одной той же тувинской юрты в зимний период года.

Fig. 2. A general view and plan of variant 2 (configuration B-2) of setting up the same Tuvan yurt in the winter season.

Условные обозначения:

$l$ - размер длины улун; $H$ - высота юрты при разных вариантах установки; $h$ - высота хана (стен) юрты при разных вариантах установки;

$$
\varnothing-\text { диаметр юрты. }
$$




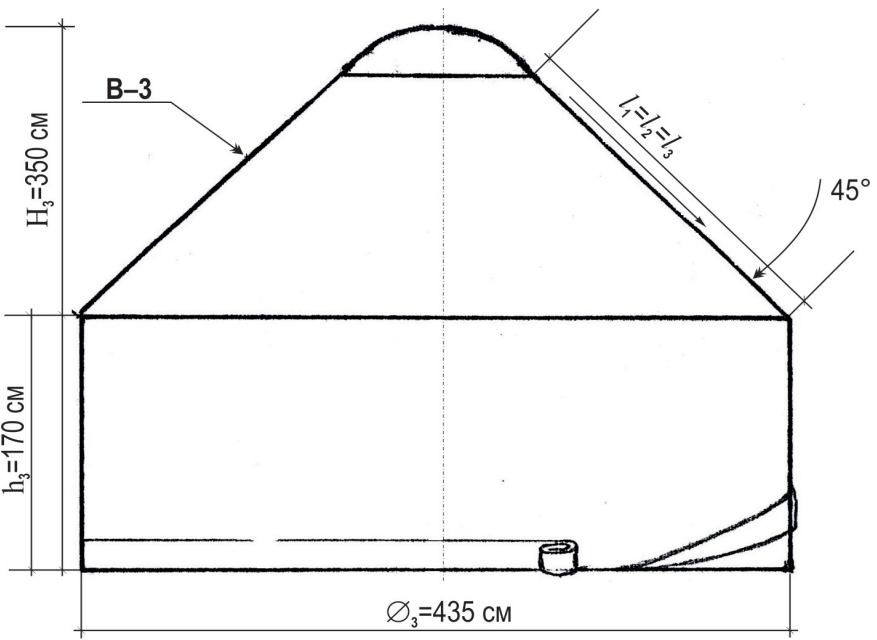

Рис. 3. Общая схема-чертёж установки варианта 3 (B-3 конфигурации) одной той же тувинской юрты в летний период (сезон) года.

Fig. 3. A general view and plan of variant 3 (configuration B-3) of setting up the same Tuvan yurt in the summer season.

\section{Условные обозначения:}

l- размер длины улун; H - высота юрты при разных вариантах установки; $h$ - высота хана (стен) юрты при разных вариантах установки; $\varnothing-$ диаметр юрты.

изменением конфигурации юрты обеспечивалось увеличение её общей площади до $\mathrm{S}_{2}=22,05$ м ${ }^{2}$ и улучшение теплосохраняемости в зимний период за счет снижения высоты юрты до $\mathrm{H}_{2}=2,80$ м и высоты хана до $\mathrm{h}_{2}=1,50 \mathrm{M}$.

Под обозначением «В-3» (на рис. 3) показана конфигурация установки юрты в летний (дождливый) период года. Здесь, наоборот, изменения достигнуты путём увеличения угла наклона улун (ынаa) стропил до $45^{\circ}$, соответственно общей высоты юрты до $\mathrm{H}_{3}=3,50 \mathrm{M}$, хана до $\mathrm{h}_{3}=1,70$ м и общей площади $\mathrm{S}_{3}=14,85 \mathrm{M}^{2}$. При таком крутом наклоне обеспечивалась быстрая стекаемость природных осадков с покрытия юрты в дождливый период и повышенная вентилируемость помещения в жаркие дни за счет увеличения высоты и придания трубообразности общей конфигурации юрты. Для обеспечения притока свежего или прохладного воздуха достаточно было открыть подпороговую доску в двери и (или) часть хаяапча с нужной стороны юрты. В крайних случаях при длительном приготовлении пищи в юрте на очаге или в очень жаркие, солнечные дни приоткрывали и нижнюю часть войлока бокового покрытия - адакы. Названия частей каркаса и покрытия юрты описаны в работе М. С. Байыр-оола (см.: Байыр-оол, 2013).

Если взять в варианте В-3 её площадь 14,85 м² как равной 100\%, то при варианте В-1 площадь $\mathrm{S}_{1}=19,625 \mathrm{M}^{2}=\mathrm{x} \%$

$\mathrm{x} \%=\frac{S_{1} \times 100}{S_{3}}=\frac{19,625 \times 100}{14,85}=132,15 \%$

То есть увеличение общей площади юрты составляет 132,15\%.

При варианте B-2 показано, что площадь $\mathrm{S}_{2}=22,05 \mathrm{M}^{2}=\mathrm{x} \%=148,48 \%$. То есть требуемое увеличение площади юрты до 148,48\% при тех же конструктивных элементах каркаса должно обеспечиваться за счёт изменения углов наклона улун (стропил) и покрытия - потолка юрты.

Требуемые возможные изменения углов наклона покрытия-потолка юрты от $45^{\circ}$ до $25^{\circ}$.

Требуемые возможные изменения высоты юрты от 2,80 м до 3,50 м, то есть на 125\%.

Исходя из таких требований и правил рассчитывались и разрабатывались методы и способы определения точных размеров, конфигураций и изготовления каждого элемента тувинской юрты, в том числе элементов её каркаса.

Конечно, оперирование современными формулами, единицами измерения, цифрами и инструментами, законами физики - это наши средства. Тувинские же мастера, чтобы соблюдать все эти выработанные веками народные требования, правила, чтобы обеспечить все эти пропорции, размеры и конфигурации, пользовались своими методами и способами определения размеров, углов наклона, проведения замеров и производства работ по изготовлению каждого элемента каркаса юрты.

\section{Традиционные методы и способы определения размеров, расчетов углов наклона конструкций}

В данном разделе мы рассмотрим некоторые традиционные методы и способы определения конфигурации, размеров, углов наклона, замера, отметки для изготовления отверстий-пазов в хараача - 
верхнем круге каркаса юрты, в которые вставляются верхние концы улун (ынаa) - жердей-стропил юрты, при соблюдении так называемых правил эде тиктинер өг. Это одно из самых ответственных соединений в конструкции каркаса, за счет которого обеспечивалось увеличение или уменьшение наклона жердей стропил, потолка юрты, общих объёмных показалелей и теплофизических характеристик жилища.

Основной базой для нашего исследования послужили традиционные правила, методы расчетов, замеров и способы изготовления, соединения данного узла, которыми пользовался народный мастер Быдаакай Шойдайович Саая. Суть метода заключалась в строгом соблюдении правил так называемого метода «два на два» при изготовлении пазов хараача (верхнего круга) - дугай хараача и верхнего четырехгранного конусообразного конца улун - стропил покрытия юрты. Общий вид (схема-чертёж) хараача и конусообразного конца улун показаны на рис. 4-5.

В частности, со слов мастеров по изготовлению каркаса юрты Б. Ш. Саая и М.-Д. С. Хертек, должны соблюдаться следующие требования: хараача должен быть изготовлен совершенно круглым (рис. 6); толщина и ширина основного корпуса хараача (из берёзы, желательно из корневой части) должен быть не менее ширины 4-х пальцев, то есть 8 см (рис. 7); нельзя просверлить или продолбить пазы насквозь хараача; для бичии (чиик) өгнун кочевой (наиболее мобильной) юрты, пазы должны быть просверлены в основной корпус хараача на глубину не более чем в две третьи его ширины (толщины), но не менее ширины 2-х, и не более 3-х пальцев, то есть около 4-5 см. Глубина, размеры, конфигурация и углы наклона всех пазов должны быть совершенно одинаковыми и оптимально приемлемы относительно толщины и ширины основного корпуса хараача; дно паза, располагаемое внутри (в теле) основного корпуса хараача, должно быть наименее меньшего (приемно-меньшего) размера и равносторонним (квадратным) прямоугольником, так же как и конец вставляемого в него улун; наклонные стенки паза хараача и концы балок - улун, вставляемые в пазы, должны быть прямоугольными, конусообразными и соответствовать по своим размерам и конфигурации требованиям сохранения целостности основного корпуса хараача; наружные размеры ширины паза должны быть в два раза больше, чем размеры дна (за

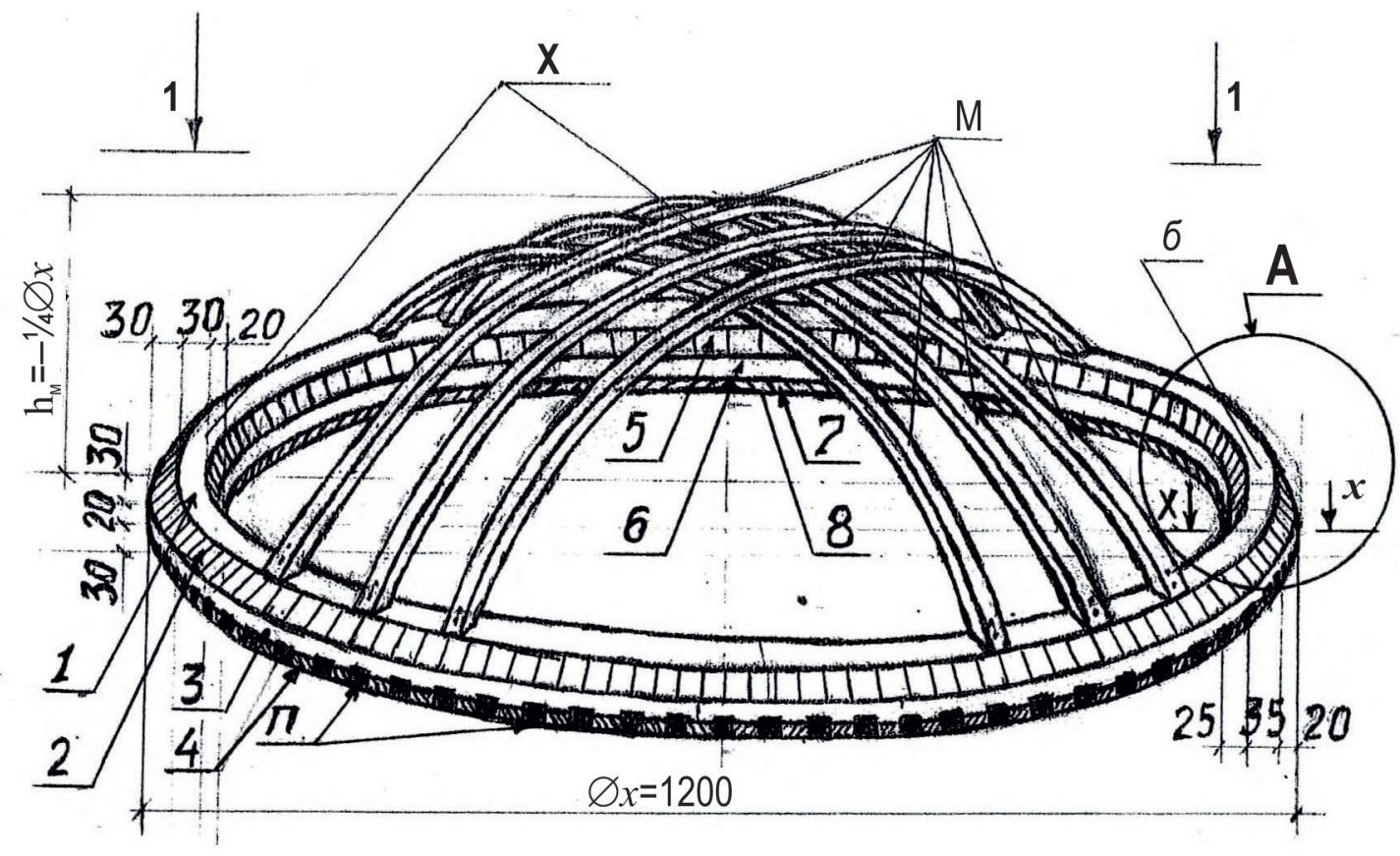

Рис. 4. Общий вид (схема-чертёж) дугай хараача.

Fig. 4. A general view and plan of the dugai haraacha.

Условные обозначения: $X$ - общий вид (схема) хараача; $M$ - мөгежелер; б - основной корпус хараача, где:

1 - верхная горизонтальная плоскость основного корпуса хараача; 2 - верхная наружная наклонная на $45^{\circ}$ плоскость основного корпуса хараача; 3 - наружная вертикальная плоскость основного корпуса хараача; 4 - наружная нижная наклонная на $35^{\circ}$ плоскость; 5 - верхная внутренная наклонная плоскость; 6-внутренная вертикальная плоскость; 7 - внутренная нижная, наклонная на $45^{\circ}$ плоскость основного корпуса хараача; 8 - нижная горизонтальная плоскость основного корпуса хараача; $\Pi$ Пазы хараача; $h_{\mathrm{M}}-$ высота мөгеже. 


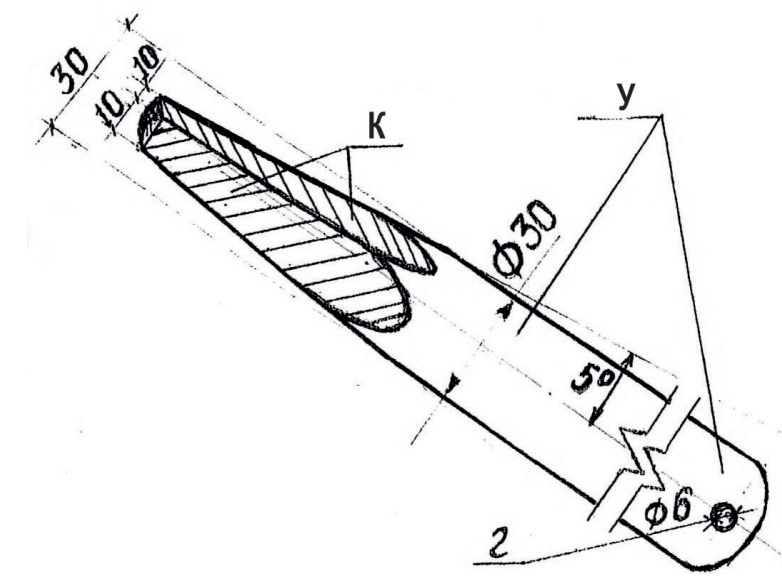

Рис. 5. Общий вид (схема-чертёж) верхнего и нижнего конца улун.

Fig. 5. A general view and plan of upper and low endings of the ulun.

Условные обозначения: У-улун (на данном рисунке показаны верхний и нижный концы улуна); K- конусообразные наклонные плоскости верхнего четырёхгранного конца улун; г - отверстие для илбэк (петли в нижнем конще улун).

Рис. 6. Общий вид сверху дугай хараача(схема-чертёж).

Fig. 6. A view from above and plan of the dugai kharaacha.

Условные обозначения:

1-1 - вид сверху; X - общий вид сверху (схема-чертёж) основного корпуса хараача (верхнего круга - полусферической конструкции); М- мөгеже (мөгежелер).

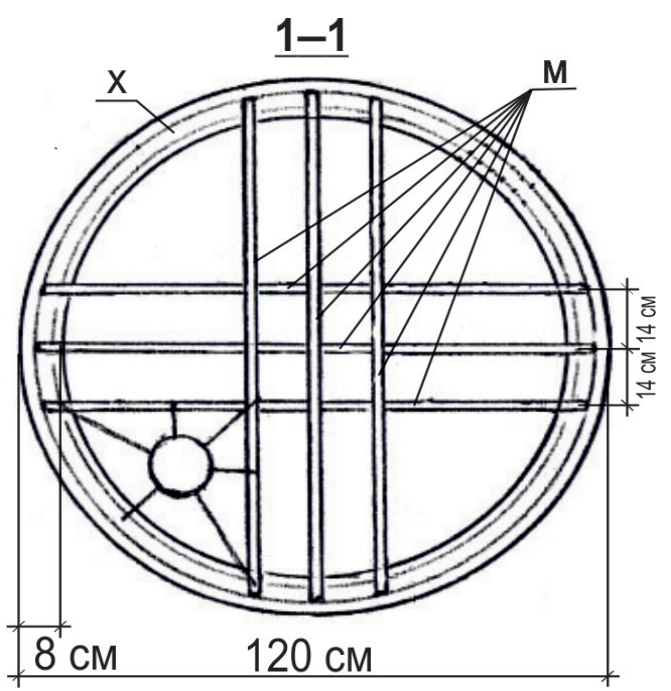

счёт конусообразности стен паза), а высота - в два раза больше ширины; наружные размеры высоты прямоугольного паза должны быть в два раза больше, чем размеры прямоугольного сечения улун на этом же месте их соединения, а по ширине одинаковыми, подходящими для вставления в паз и т. д.

Соблюдение всех правил при изготовлении пазов хараача исключало появление повышенного поперечно-раскалывающего и продольного напряжения и как следствие - продольного разлома вдоль отверстий-пазов хараача и поперечного излома верхних четырёхгранных конусообразно заточенных концов улун - жердей-стропил потолка юрты, что и было особенно необходимо при изменении угла наклона улун при разных (сезонных) вариантах установки юрт (см. puc. 8). Поэтому необходимо было строго придерживаться традиционных стандартов.

На puc. 8 показаны схемы-чертежи некоторых традиционных методов и способов определения размеров, конфигурации, углов наклона граней-плоскостей при изготовлении основного корпуса хараача - верхнего круга каркаса юрты, при использовании метода сэс кырлыг (восьмигранника) и наклонных отверстий-пазов в нём. При данной методике сначала изготавливают в соответствии с ранее расчитанными размерами основной корпус хараача в виде совершенно правильного четырёхгранного круга (рuс. 7). В рассматриваемом варианте его размеры составляют: диаметр по наружной вертикальной грани-плоскости круга составляет 1200 мм, по внутренней вертикальной граниплоскости = 1040 мм; размеры поперечного прямоугольного сечения заготовки составляют $80 \times 80$ мм. Чтобы изготовить из него восмигранную заготовку в соответствии с заранее рассчитанными углами наклона новых граней-плоскостей, наносят отметки в виде продольных линий вдоль плоскостей корпуса с использованием (с помощью) инстумента дорт-кортук (традиционного измерительного инструмента, состоящего из корпуса и паралельно вставленных в него и выдвигающихся двух круглых реек с металическими острыми шипами, аналог современного штангенциркуля), на все четыре, чисто обработанные поверхности, опять же в соответствии с заранее расчитанными по ширине размерами. 
Рис. 7. Общий вид (схема-чертёж) 4-хгранной заготовки подготовленной для изготовления 8-мигранного основного корпуса хараача.

Fig. 7. A general view of a tetrahedral stock prepared for making an octahedral frame of the haraacha.

Условные обозначения: 3 - четырёхгранная заготовка для основного корпуса хараача; У-отмеченные участки-углы (части) 4-хгранного заготовки, которые необходимо удалить для получения 8-гранного сечения основного корпуса хараача с определёнными размерами и углами наклона граней-плоскостей; $A-$ узел (вид) поперечного сечения-разреза заготовки $X$-Х с указанием расчитанных размеров, конфигурации и углов наклона гранней-плоскостей основного корпуса хараача и предполагаемого место расположения трапециеобразного отверстия-паза хараача.

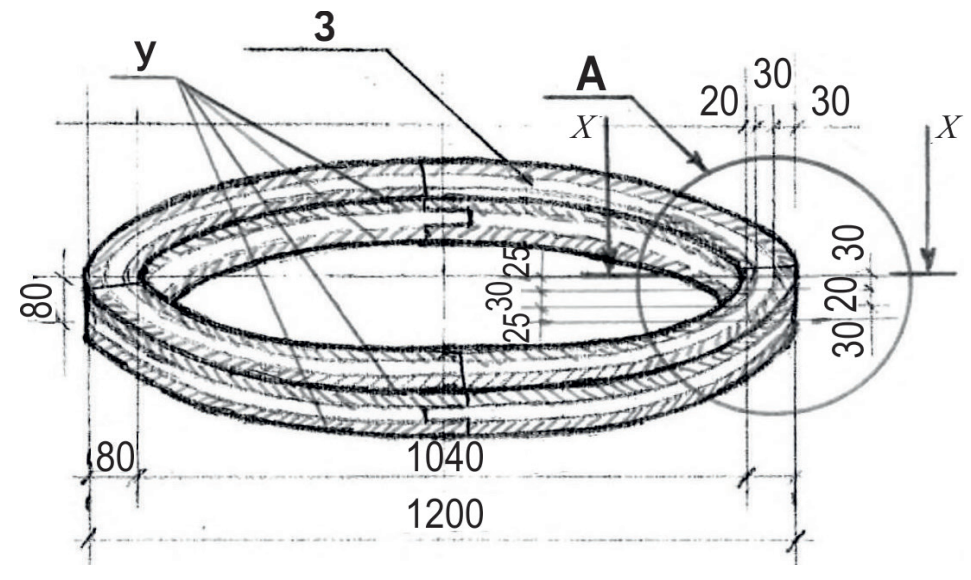

Рис. 8. Чертежи-схемы некоторых традиционных методов и способов определения размеров, конфигурации, углов наклона плоскостей основного корпуса хараача (верхнего круга юрты) и отверстий-пазов в нём и их изготовления.

Fig. 8. Drafts and plans of some traditional methods of measuring the size, configuration and slope angles of the planes of the main frame of the kharaacha (the upper circle of the yurt), its grooves and the process of making them.

Условные обозначения:

Узел " $A$ ", сечение $X-X-$ вид поперечного сечения (разреза) заготовки основного корпуса хараача, с указанием расчитанных размеров, конфигурации и углов наклона её граней-плоскостей и предполагаемого место расположения трапециеобразного отверстия-паза и их конфигурации внутри заготовки основного корпуса хараача; П - общий вид (чертёж-схема) поперечного разреза пазов хараача; У- общий вид (чертёж-схема) возможных вариантов установки (расположения) углов наклона улун (балки стропилы, которые служат несущими конструкциями для всего покрытия юрты (на данном рисунке показаны три варианта уклонов улун при сезонных установках юрты, и соответствующее двухкратное расширение высоты наружных размеров отверствий пазов хараача); П-П-вид на пазов хараача со стороны нижних концов улун.

На рис. 8 чертеже-схеме разреза $\mathrm{X}-\mathrm{X}$ узла «А» показаны методы определения углов наклона всех четырех новых (дополнительных) наклонных поверхностей основного корпуса хараача и требуемые углы наклона улун - У, в 3-х вариантах установки юрты. В частности, в правом верхнем углу поперечного разреза X-X (x1), 4-хгранной заготовки основного корпуса хараача - 3,( $\left.\mathrm{X}_{1}\right)$ (рис. 7 , рис. 8) показаны методы отмера, отметки и создания (формирования) верхней наружной наклонной плоскости основного корпуса хараача с углом наклона в $45^{\circ}$, которое осуществляется способом обмера и отметки одинаковых расстояний по 30 мм, от верхнего наружного угла (края), заранее заготовленного пока еще 4-хгранного основного корпуса хараача - 3, по верхнему и наружному его плоскостям-поверхностям и через эти отметки, вдоль по верхнему и наружному поверхностям заготовки, с использованием (с помощю) инстумента дорт-кортук (традиционного измерительного инструмента, состоящего из корпуса и паралельно вставленных в него и выдвигающихся двух круглых реек с металическими острыми шипами, аналог современного штангенциркуля), проводятся линии, до которых и удаляются, оттесываются и обстругиваются намеченные части с применением инструмента кержек (тувинского традиционного плотничьего инструмента, аналога современного тесло), и обработкой (строганием) поверхности до этих отмеченных линий (см. рис. 7), 3 - общий вид заготовки основного корпуса хараача. Таким образом, после удаления угловой части заготовки получается верхняя наружная наклонная поверхность -2 (рис. 4) основного корпуса хараача $-\mathrm{X}$, с уклоном в $45^{\circ}$, на которую во время 
эксплуатации укладываются верхний край войлочных покрытий, а над ними нижняя часть өреге самого верхнего прямоугольного (квадратного) покрытия юрты, которым закрывают полностью полусферическую верхную часть хараача, и открывают в дневное время до половину хараача. Өреге изготавливают из войлока и тканей (в настоящее время еще и из брезента), используя специальные традиционные методы раскроя и шитья. Подобным же методом, замерив расстояния от нижнего наружного края заготовки основного корпуса хараача по нижней площадке в 20 мм и по наружной площадке 30 мм, отмечается продольной линией граница удаления вдоль заготовки, по нижней и наружной его поверхностям. После удаления отмеченных частей заготовки основного корпуса хараача и их окончательной чистой обработки получается нижная наружная продольная площадка 4 (рис. 4 ), с углом наклона в $35^{\circ}$.

На этой продольной наклонной площадке и производятся замеры, пометки и впоследствии изготовление пазов хараача. Для этого прежде всего определяли расстояние Р между пазами (по их осям), методом замера длины наружной плоскости хараача и её делением на количество улун. Получается, что данное расстояние определяли по формуле $\mathrm{P}=\frac{\pi}{\mathrm{K}}$, где $Л$ - длина наружной окружности хараача, Ку количество улун в изготавливаемом варианте ${ }^{\mathrm{K}_{\text {у }}}$ караса юрты. В нашем варианте стены юрт состоит из 6-ти звеньев 12-главых хана и двери с шириной верха 110 см, на котором должен располагаться 6 улун. Значит, количество улун будет Ку = (6 х 12)+6 = 78 шт. Длина наружной окружности хараача $\pi=\pi R=3,14 \times 1200 \mathrm{мm}=3768$ мм. Расстояние между пазов по осям получается $\mathrm{P}=3768 / 78=48,3=48$ мм. Исходя из данного рассчитанного расстояния, определяется ширина и высота наружных (наибольших) размеров пазов, для нанесения линий-отметок на места предполагаемого их расположения.

В соответствии с требованиями максимального сохранения целостности основного корпуса хараача и принятых правил, расстояния между её пазами должны быть больше, чем ширина самих пазов. Для данного варианта, то есть при расстоянии между осями пазов в 48 мм, при условии соблюдения требований, наиболее приемлемым является определение размеров ширины паза в 20 мм, а расстояние между ними в 28 мм. Соответственно, по методике «два на два», размер дна пазов определяется 20×2=10 мм, а высота наружных размеров пазов 20×2=40 мм (рис. 12). Наклон стен пазов по высоте: нижная сторона-стенки пазов $-45+5=50^{\circ}$, верхная сторона-стенки пазов $-25-5=20^{\circ}$.

\section{Традиционные методы и способы изготовления пазов хараача}

При производстве работ по изготовлению пазов хараяча в соответствии с традиционными требованиями объязательным условием являлось соблюдение заранее рассчитанных размеров, углов наклона, и конфигураций трапециевидных конусообразных 4-хгранных стен пазов и их расположения. Для выполнения работ в безусловном соблюдении соответствия с расчетами, использовались метод хепке кылыр (делать в форме). Для этого заготавливали крестообразную форму-основание с наклонными направляющими установками и с передвижными стойками регулирования и закрепления на форме-основания заготовки основного корпуса хараача (рис. 9). Наклонные направляющие установки предназначались для проведения работ точного сверления встречно-наклонных боковых (верхнего и нижнего) отверстий стен пазов в заготовке основного корпуса хараача ( puc. 10 u 11).

Для удобства при определении месть расположения пазов на основном корпусе хараяча и нанесения чертежей (отметок-линий) определённых размеров пазов на нижную наружную наклонную плоскость заготовки основного корпуса хараача - 3, и для эффективного проведения дальнейших работ по сверлению и изготовлению самих пазов, подготовленная для сверления пазов 8-гранная заготовка основного корпуса хараача укладывается, верхом вниз, на основу - Ф, между опорными регулирующими стойками - Р и направляющими устройствами - Н и Б, и надёжно закрепляется.

Далее на наружной наклонной плоскости заготовки основного корпуса хараача отмеряется ранее полученное расчетным путём расстояние - 48 мм и ставятся поперечные линии-отметки на плоскости, по всей длине круга, то есть 78 поперечных отметок-линий которые будут являться ориентирами осями предполагаемых пазов хараача.

На рис. 12 «Вид П-П» - показано, что далее от осей пазов отмеряются и отмечаются размеры дна пазов 10×10 мм, которые будут изготовлены (сформированы) и находиться внутри основного корпуса хараача, в глубине 45 мм. Потом отмеряются и отмечаются наружные размеры пазов хараача, по ширине и высоте предполагаемых трапециевидных стен пазов. То есть сперва отмеряется от ранее отмеченных осей предполагаемых пазов хараача в обе стороны по 5 мм (итого 10 мм) - это будет 
ширина равностороннего (квадратного) дна паза. Отмеряя еще по 5 мм, получают и отмечают ширину наружных размеров паза хараача, равную 10+10=20 мм (в два раза больше ширины дна паза).

Размеры наружных краев стен пазов хараача по высоте замеряются и отмечаются от нижнего края нижней наружной наклонной плоскости заготовки основного корпуса хараача. Сперва отмеряются всего лишь по 2 мм и отмечаются как нижние наружные границы стен пазова. Затем, уже от этой отметки отмеряют 40 мм - высоту наружного размера (краёв) пазов (в соответствии с правилом - в два раза больше, чем ширина) и отмечают прямой линией (рис. 12). При правильном определении размеров данная линия (верхний край) высоты стен пазов должна заходить на 5 мм в наружную вертикальную плоскость основного корпуса хараача, образуя своеобразную щель на краю плоскости. Впоследствии она будет (служить) использована как направляющая щель-желоб для вставления улун в пазы хараача, при монтаже каркаса юрты. Некоторые самые опытные мастера делали как продолжение этой щели еще желоб-углубление на всю ширину наружной плоскости основного корпуса хараача, по которой и подводили улун к пазам хараача при монтаже каркаса юрт.

Затем по отмеченным точкам вычерчиваются прямоуголники размерами $20 \times 40$ мм - наружные размеры предполагаемых трапециевидных пазов хараача, по которым и будут высверлены и вырезаны (изготовлены) пазы хараача (рис. 12).

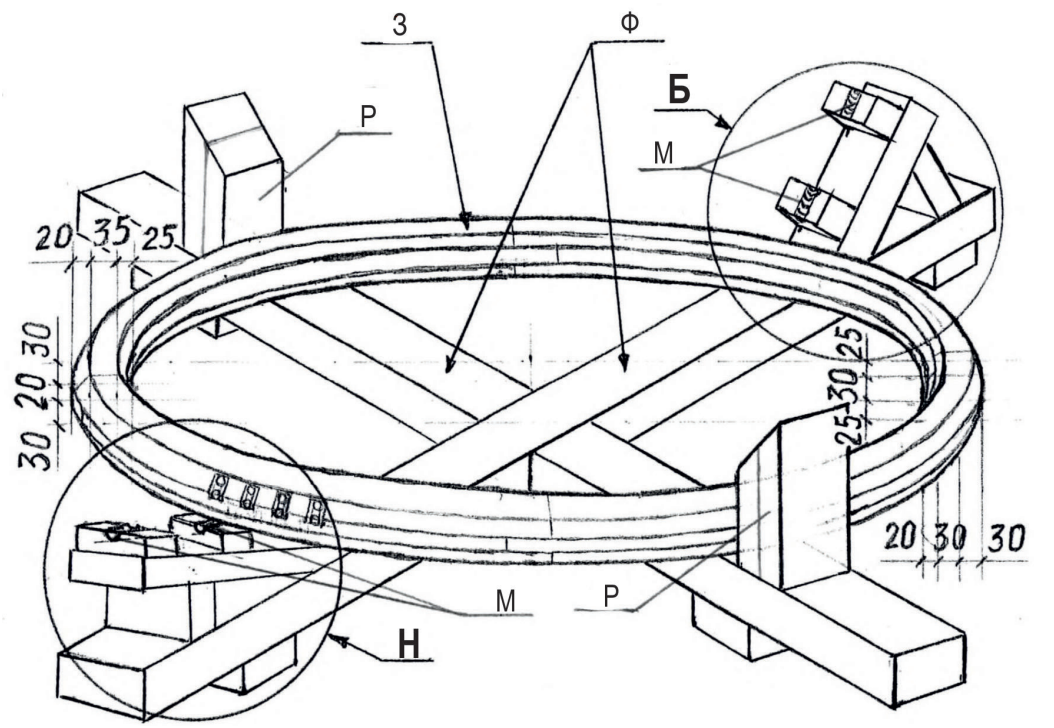

Рис. 9. Общий вид (чертежи-схемы) формыоснования с наклонными направляющими установками, и с передвижными стойками регулирования и закрепления на нём заготовки основного корпуса хараача.

Fig. 9. A general view and plan of the foundation block with slanted runner slides and movable adjustable posts to hold the stock of the kharaacha.

Условные обозначения: 3-восмигранная заготовка основного корпуса хараача с отмеченными (в соответствии с ранее расчитанными параметрами) местами расположения пазов хараача; Ф-форма-основания, на котором укладывается заготовка хараача и закрепляются угловые направляющие для свёрл; $P$ - стойки регулируемые; узел $5-$ направляющая установка обеспечения углов наклона сверления отверстий под $50^{\circ}$; узел $H$ - направляющая установка углов наклона под $20^{\circ}$; M-места (полукруглые пазы) установки сверла; О - основы направляющих досок установки.

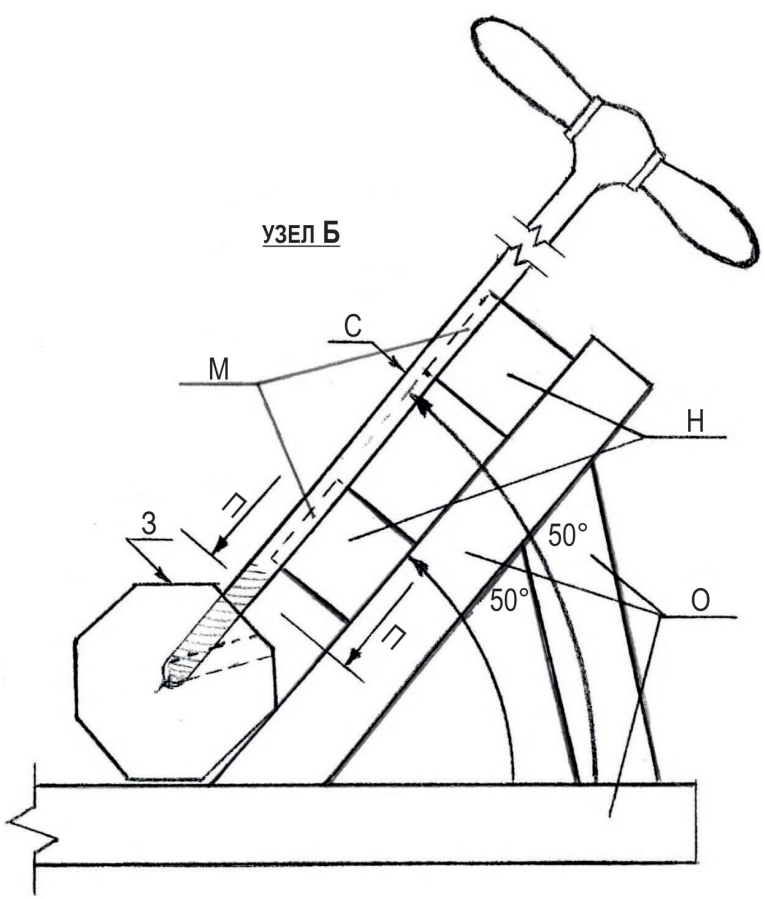

Рис. 10. Общий вид (чертежи-схемы) узел Б- направляющая установка обеспечения углов наклона сверления отверстий под $50^{\circ}$.

Fig. 10. A general view and plan, unit $B$ - the runner slide to control slant angles for drilling holes at $50^{\circ}$.

Условные обозначения:

$C$ - свёрла установленные для сверления по краю нижних наклонных в $50^{\circ}$ стен пазов хараача;

$M$ - места (полукруглые пазы) установки сверла под $50^{\circ}$; H - направляющие установки обеспечения углов наклона сверления отверстий под $50^{\circ} ; \mathrm{O}-$ основы направляющих досок установки; вид П-П-вид на отмеченные места устройства пазов на наружной наклонной плоскости заготовки хараача со стороны сверления; 3 - вид поперечного сечения 8-мигранной заготовки основного корпуса хараача. 


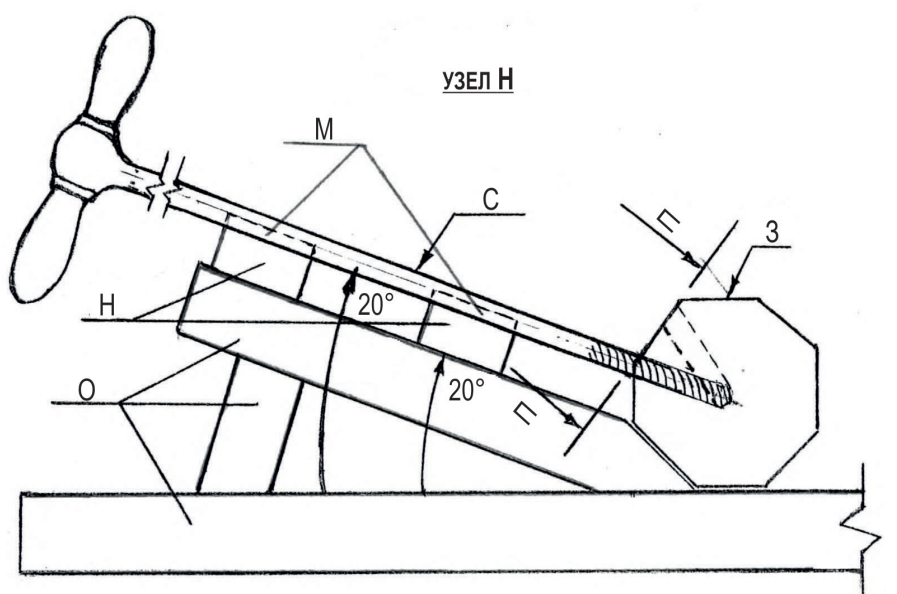

Рис. 11. Общий вид (чертежи-схемы) узел $H$ - направляющей установки обеспечения углов наклона сверления отверстий под $20^{\circ}$.

Fig. 11. A general view and plan, unit $H-$ the runner slide to control slant angles for drilling holes at $20^{\circ}$.

Условные обозначения: $M$ - места (полукруглые пазы) установки сверла под $20^{\circ}$; C - свёрла установленные для сверления по краю верхних наклонных в $20^{\circ}$ стен пазов хараача; $H$ - направляющие установки обеспечения углов наклона сверления отверстий под $20^{\circ}$; O- основы направляющих досок установки; вид П-П-вид на отмеченные места устройства пазов на наружной наклонной плоскости заготовки хараача со стороны сверления; 3 - вид поперечного сечения 8 -мигранной заготовки основного корпуса хараача.
Рис. 12. Общий вид (чертежи-схемы) вид П-П-вид, со стороны сверления, на отмеченные и вычерченные места устройства пазов на наружной наклонной плоскости заготовки основного корпуса хараача.

Fig. 12. A general view (along the $\Pi-\Pi$ line) from the drilling direction of areas marked for grooves on the external sloped plane of the stock of the kharaacha.

\section{Условные обозначения:}

$\Pi_{1}, \Pi_{2}, \Pi_{3}$ и т. Ә. (всего, по периметру д/б 78 прямоугольников) - места расположения пазов хараача, с вычерченными отметками размеров и конфигураций предполагаемых пазов хараача;

$P$ - расстояния между осями пазов хараача, отмечаемые на наружной поверхности заготовки основного корпуса хараача; Ц - центры всречных сверлений по наклонным плоскостям стен пазов; O- окружности (круги), внутри которых должен сверлиться верхний и нижний наклонные стенки пазов хараача.

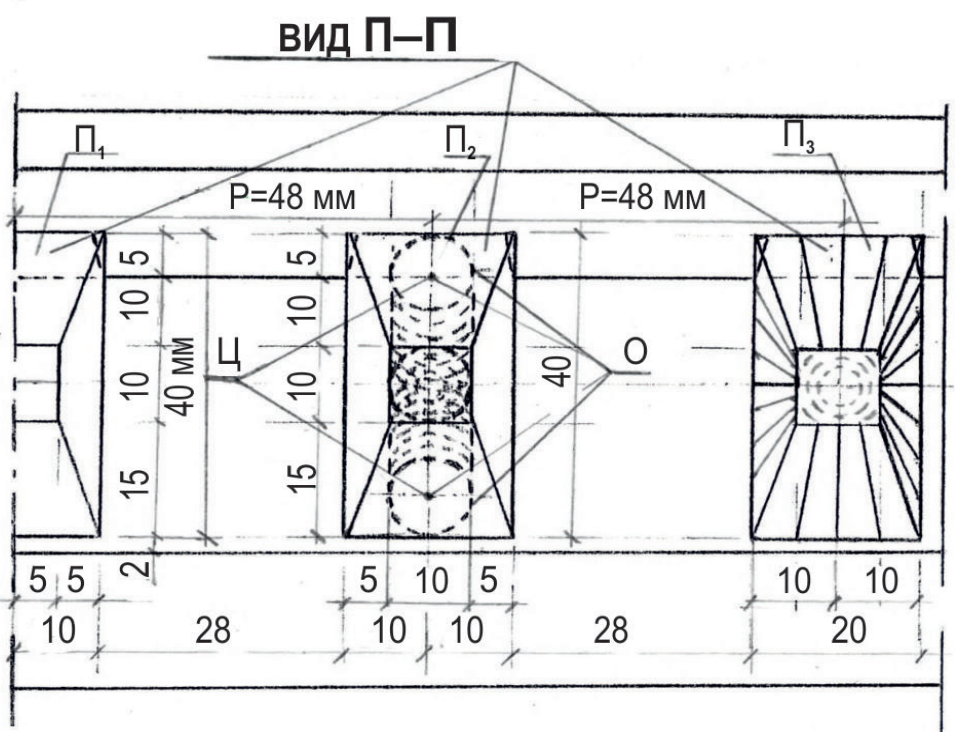

Для точности сверления отверстий и в последствии дальнейшего изготовления по ним пазов хараача на нижнем и верхнем краю прямоугольников, на осях предполагаемых пазов отмечаются круги - O, с диаметром 10 мм, и определяется точки центров сверления - Ц, по которым и будет производиться сверление заготовки основного корпуса хараача, для изготовления (формирования) нижнего и верхнего наклонных стен пазов хараяч (рис. 12).

Далее на наклонных направляющих установках - Н, «Узел Б» (рис. 10), в специально подготовленные углубления-места (щели) - M, с углом наклона на $50^{\circ}$ устанавливаются свёрла соответствующего диаметра (в нашем варианте - 10 мм) и закрепляются с применением кожаных или плетёных ремешков. Относительно плоскости и горизонтальной оси заготовки корпуса хараача сверление каждого паза должно производиться строго под прямым углом $\left(90^{\circ}\right)$. Путём прокручивания заготовки корпуса хараача -3 на основе формы - Ф к острому концу подготовленного сверла подводится центр - Ц, ранее отмеченного на заготовке корпуса хараача круга - O, и начинается сверление нижнего края паза под углом $50^{\circ}$. Сверление производится до заранее определенной и отмеченной (в том числе и на сверле) глубины паза (в нашем варианте 45 мм). Затем сверло отводится. Следующим прокручиванием заготовки корпуса хараача к сверлу подводится следующий центр - Ц отмеченного круга О стенки следующего паза и просверливается подобным же образом, до отмеченной глубины. Таким образом просверливаются все нижние 78 стенки пазов с 50-градусным уклоном.

Такими же способом просверливаются все 78 верхних встречных наклонных стенок пазов, только с применением другой (второй) направляющей установки - $\mathrm{H}$ «Узел Н» (рис. 11), подготовленной для сверления с углом наклона в $20^{\circ}$, на ту же отмеченную глубину 45 мм. При правильном выполнении 
наклонно-встречных сверлений с применением двух направляющих установок с различными углами наклонов, концы просверлённых отверстий должны сходиться в одном месте, образуя дно заготавливаемого трапециеобразного паза с диаметром 10 мм, на глубине 45 мм заготовки корпуса хараача, которая в последствии переделывается, при оттёсывании стен пазов, в квадрат с размерами $10 \times 10$ мм.

Верхний край верхнего просверлённого отверстия будет являться границей верхней наклонной трапециевидной стенки паза, одновременно являясь ориентиром для доработки - оттесания и формирования стенки соответствуюших параметров с использованием инструмента шүүче (традиционного плотничного инструмента тувинцев, аналог современной стамески) (в нашем варианте размер ширины резца шүүче должен быть не более 10 мм). Параллельно производится оттесание, доработка и боковых наклонных конусообразных трапециевидных стен пазов. При этом необходимо ориентироваться на те же концы просверленных отверстий, внутри заранее начерченного прямоугольника наружных размеров паза $-\Pi_{1}, \Pi_{2}, \Pi_{3}$ (рис. 12) и т. д. (всего 78 прямоугольников с отметками).

Таким же образом производится формирование нижних наклонных и боковых стен всех 78 пазов. При правильном выполнении всех работ получаются совершенно одинаковые трапециевидные пазы с соответствующими заранее расчитанными размерами, уклонами и конфигурацией.

\section{Заключение}

В результате строгого соблюдения традиционных требований, правил и методов определения размеров, углов наклона и проведения всех подготовительных и основных работ по изготовлению пазов хараача, получаются совершенно одинаковые пазы, способные обеспечить расположение улун под разным углом наклона. Их трапециевидные конфигурации и расчетно-определённые точные размеры, углы наклонов стен пазов обеспечивают исключение поперечного излома верхних концов улун и продольного разлома основного корпуса хараяча вдоль линии расположения пазов даже при таком значительном изменении углов наклона улун, которые составляют от $25^{\circ}$ до $45^{\circ}$.

В рассматриваемом варианте каркаса юрты глубина пазов $=45$ мм, что соответствует требованиям соотношения к размерам ширины поперечного сечения основного корпуса хараача - 80 мм; наименьшие размеры дна пазов = 10×10 мм, что соответствует требованиям обеспечения целостности основного корпуса хараача и размерам верхних заострённых конусообразных концов улун, вставляемых в пазы; размеры ширины наружных краёв пазов = 20 мм, что соответствует размерам ширины улун на месте их примыкания и требованиям метода «два на два» относительно размеров дна, так же как наружные размеры высоты пазов 40 мм.

Эти размеры являются оптимальными при среднем размере диаметра юрты 5 метров и диаметре хараача 1,2 м и ширины (толщины) основного корпуса хараяча - 8 см. При данных размерах юрты и хараача, размеры пазов могут быть увеличены, но не более чем на $1 / 4$ (то есть не более чем на $25 \%$ от показанных). При изготовлении каркаса юрт большего размера, соответственно, увеличиваются размеры пазов, но без изменении её расчитанной и сформированной конфигурации, углов наклона стен пазов и соотношений их размеров. Это дает возможность устанавливать одну и ту же юрту в различных вариантах, с различными геометрическими, объёмными и тепло-физическими показателями.

В данной работе мы рассмотрели традиционные методы и способы определения размеров, углов наклона и изготовления только одного из многочисленных узлов (в том числе соединений (примыканий) различных частей конструкций), элементов каркаса юрты - пазов основного корпуса хаpaача. А подобных элементов, узлов соединения, примыкания и крепления в каркасе юрты очень много. В связи с чем и возникают вопросы и проблемы при изготовлении и эксплуатации каркасов юрт в современных условиях.

Подобные исследования необходимы для возрождения, сохранения и развития традиционных видов хозяйствования и туризма, в том числе при реализации таких социально значимых программ, ориентированных на этнос, как губернаторский проект «Кыштаг для молодой семьи» ${ }^{1}$ цель которого помочь молодым селянам организовать семейные животноводческие фермы.

${ }^{1}$ В Туве стартует губернаторский проект «Кыштаг для молодой семьи» [Электронный ресурс] // Официальный портал Республики Тыва. URL: http://gov.tuva.ru/press_center/news/agriculture/22114/ (дата обращения: 05.05.2020). 


\section{Благодарности}

Выражаю признательность всем организациям, коллегам, учёным, специалистам и народным мастерам, которые мне помогали (оказывали содействие) в разные годы при проведении данных исследований: Национальному музею имени Алдан-Маадыр Республики Тыва, в том числе научному сотруднику отдела краеведения и туризма Б. С. Майны, народному мастеру-камнерезу, лауреату Государственной премии РФ им. И. Е. Репина К. М. Саая (1931 г. р.), народному мастеру-камнерезу М.-Д. С. Хертек (1915-1973), народному мастеру Б. Ш. Саая (1905-1975), учёным и специалистам ТувИКОПР СО РАН: Л. А. Непомнящей, И. П. Принцевой, Ю. Ю. Самбыла и др.

\section{СПИСОК ЛИТЕРАТУРЫ}

Байыр-оол, М. С. (2013) Юрта в тувинской традиционной культуре [Электронный ресурс] // Новые исследования Тувы. № 2. C. 67-79. URL: https://nit.tuva.asia/nit/article/view/242 (дата обращения: 01.07.2020).

Бохоева, Л. А., Балданов, А. Б. (2013) Компьютерное моделирование каркаса юрты с применением композиционных материалов // Вестник ВСГУТУ. № 4 (43). С. 35-38.

Вайнштейн, С. И. (1991) Мир кочевников центра Азии. М. : Наука. 296 с.

Кан-оол, М. А., Ондар, А. Б. (2014) Юрта: предметы быта тувинцев // Актуальные проблемы исследования этноэкологических и этнокультурных традиций народов Саяно-Алтая: Материалы II междунар. науч.-практ. конф. молодых учёных, аспирантов и студентов, посвящ. 100-летию единения России и Тувы и в рамках реализации мероприятий Программы развития деятельности студенческих объединений / отв. ред. О. М. Хомушку. Кызыл : ТувГУ ; ХГУ им. Н. Ф. Катанова. 155 с. С. 73-74.

Кокова, Е. А., Толмашов, А. Г. (2014) Хакасская юрта в контексте этноматематических идей // Актуальные проблемы исследования этноэкологических и этнокультурных традиций народов Саяно-Алтая: Материалы II междунар. науч.-практ. конф. молодых учёных, аспирантов и студентов, посвящ. 100-летию единения России и Тувы и в рамках реализации мероприятий Программы развития деятельности студенческих объединений / отв. ред. О. М. Хомушку. Кызыл : ТувГУ ; ХГУ им. Н. Ф. Катанова. 155 с. С. 20.

Майдар, Д., Пюрвеев, Д. Б. (1980) От кочевой до мобильной архитектуры. М. : Стройиздат. 215 с.

Никифоров, С. О., Михайлов, В. Н., Никифоров, Б. С. (2014) Особенности дизайна монгольских юрт (ГЭР)О: генезис, типология, каркасно-модульные технологии и их трансформация // Вестник Бурятского научного центра СО РАН. № 1 (13). С. 99-116.

Ултургашева, О. Г., Тиникова, Ю. К. (2013) Юрта - хранительница традиционных обрядов кочевых народов Азии (на примере хакасской юрты) // Вестник КемГУКИ. № 22. С. 52-59.

Дата поступления: 12.07.2020 г.

\section{REFERENCES}

Baiyr-ool, M. S. (2013) Iurta v tuvinskoi traditsionnoi kul'ture [The yurt in traditional Tuvan culture]. New Research of Tuva, no. 2, pp. 67-79 [online] Available at: https://nit.tuva.asia/nit/article/view/242 (access date: 01.07.2020). (In Russ.).

Bokhoeva, L. A. and Baldanov, A. B. (2013) Komp'iuternoe modelirovanie karkasa iurty s primeneniem kompozitsionnykh materialov [Computer modeling of the yurt's frame using composite materials]. Vestnik VSGUTU, no. 4 (43), pp. 35-38. (In Russ.).

Vainshtein, S. I. (1991) Mir kochevnikov tsentra Azii [The world of nomads of the center of Asia]. Moscow, Nauka. 296 p. (In Russ.).

Kan-ool, M. A. and Ondar, A. B. (2014) Iurta: predmety byta tuvintsev [The yurt: everyday objects of Tuvans]. In: Aktual'nye problemy issledovaniia etnoekologicheskikh $i$ etnokul'turnykh traditsii narodov Saiano-Altaia [Urgent issues of researching ethnoecological and ethno-cultural traditions of the Sayano-Altai peoples]: Proceedings of the 2nd International conference of young scientists, postgraduates and students. 100th anniversary of the unity of Russia and Tuva and in the framework of the implementing the program for the development of student associations / ed. by O. M. Khomushku. Kyzyl, TuvGU; KhGU im. N. F. Katanova. 155 p. Pp. 73-74. (In Russ.).

Kokova, E. A. and Tolmashov, A. G. (2014) Khakasskaia iurta v kontekste etnomatematicheskikh idei [Khakass yurt in the context of ethnomathematical ideas]. In: Aktual'nye problemy issledovaniia etnoekologicheskikh i etnokul'turnykh traditsii narodov Saiano-Altaia [Urgent issues of researching ethnoecological and ethno-cultural traditions of the SayanoAltai peoples]: Proceedings of the 2nd International conference of young scientists, postgraduates and students. 100th 
anniversary of the unity of Russia and Tuva and in the framework of the implementing the program for the development of student associations / ed. by O. M. Khomushku. Kyzyl, TuvGU; KhGU im. N. F. Katanova. 155 p. P. 20. (In Russ.).

Maidar, D. and Piurveev, D. B. (1980) Ot kochevoi do mobil'noi arkhitektury [From nomadic to mobile architecture]. Moscow, Stroiizdat. 215 p. (In Russ.).

Nikiforov, S. O., Mikhailov, V. N. and Nikiforov, B. S. (2014) Osobennosti dizaina mongol'skikh iurt (GER)O: genezis, tipologiia, karkasno-modul'nye tekhnologii i ikh transformatsiia [Design features of Mongolian yurts (GER)O: Genesis, typology, frame-modular technologies and their transformation]. Vestnik Buriatskogo nauchnogo tsentra SO RAN, no. 1 (13), pp. 99-116. (In Russ.).

Ulturgasheva, O. G. and Tinikova, Yu. K. (2013) Iurta - khranitel'nitsa traditsionnykh obriadov kochevykh narodov Azii (na primere khakasskoi iurty) [The yurt as a keeper of traditional rites of nomadic peoples of Asia: the case of the Khakass yurt)]. Vestnik KemGUKI, no. 22, pp. 52-59. (In Russ.).

Submission date: 12.07.2020. 